\title{
The Impact of Coffee Certification on the Economic Performance of Indonesian Actors
}

Citation for published version (APA):

Sri Astuti Soeryaningrum Agustin, E. (2018). The Impact of Coffee Certification on the Economic Performance of Indonesian Actors. [Doctoral Thesis, Maastricht University]. Datawyse / Universitaire Pers Maastricht. https://doi.org/10.26481/dis.20180508es

Document status and date:

Published: 01/01/2018

DOI:

10.26481/dis.20180508es

Document Version:

Publisher's PDF, also known as Version of record

\section{Please check the document version of this publication:}

- A submitted manuscript is the version of the article upon submission and before peer-review. There can be important differences between the submitted version and the official published version of record.

People interested in the research are advised to contact the author for the final version of the publication, or visit the DOI to the publisher's website.

- The final author version and the galley proof are versions of the publication after peer review.

- The final published version features the final layout of the paper including the volume, issue and page numbers.

Link to publication

\footnotetext{
General rights Owners
rights.

- You may freely distribute the URL identifying the publication in the public portal. please follow below link for the End User Agreement:

www.umlib.nl/taverne-license

Take down policy

If you believe that this document breaches copyright please contact us at:

repository@maastrichtuniversity.nl

providing details and we will investigate your claim.
}

Copyright and moral rights for the publications made accessible in the public portal are retained by the authors and/or other copyright owners and it is a condition of accessing publications that users recognise and abide by the legal requirements associated with these

- Users may download and print one copy of any publication from the public portal for the purpose of private study or research.

- You may not further distribute the material or use it for any profit-making activity or commercial gain

If the publication is distributed under the terms of Article $25 \mathrm{fa}$ of the Dutch Copyright Act, indicated by the "Taverne" license above, 


\section{Summary}

The prevailing assumption among Western consumers is that buying certified coffee contributes positively to the economic performance of Southern actors, particularly smallholder farmers. Previous studies also show that economic prospects are among the most important reasons for farmers to participate in certification. However, studies researching the impacts of certification on farmers' livelihoods show conflicting and inconclusive results. Some reveal that certification has a direct and positive impact on farmers' income by guaranteeing minimum prices and contributing to a higher coffee productivity. Others however, conclude that certification negatively affectscoffee yields and production costs, and therewith-coffee revenues, whereas a third group of research concludes that certification has no significant impact on economic performance at all. With this dissertation I connect to this inconclusiveness, as I want to contribute to a better understanding of the influence of coffee certification on the economic performance of Indonesian smallholder farmers. The main research question is:

What is, given the Indonesian context and characteristics of coffee certification, a useful way to analyze impacts of certification on economic performance of smallholder farmers?

More concretely, this dissertation contributes to the existing literature in three ways:

First, current research tends to assume a unidirectional causal relationship between certification and economic impact. I add a consideration about the position of the farmers in the value chain, and an interpretation of their economic benefits compared to other actors in the value chain. Different from existing research, I will treat the certified and conventional coffee value chain as interchangeable chains that are connected via personal interlinkages among actors. Second, I observed that current research generally neglects the role of factors mediating the relationship between certification and economic performance. In my research I add consideration of the potentially mediating influence of different types of relationships of farmers across marketing channels and partnerships. Third, I observed another limitation of current studies, which relates to their conceptualization of economic performance, namely as a microeconomic concept taking into account quantitative indicators on an individual level. In this dissertation I do the same, but add an analysis of economic performance from a broader perspective by focusing on monetary and non-monetary indicators for poverty alleviation and comparing these data for certified and conventional coffee farmers. 
Based on these considerations I formulated the following operational research questions:

- How and to what extent does sustainability certification contribute to the economic performance of Indonesian farmers in the coffee value chain?

- How is the economic rent of sustainability certification distributed among the actors in the coffee value chain and to what extent are smallholder farmers able to profit economically from participating in certification?

- How and to what extent do different types of relationships of farmers (particularly the marketing channels and partnerships they are in) influence the economic performance of the smallholder farmers?

- How and to what extent do certified and conventional smallholder farmers differ in terms of poverty and what can we expect from sustainability certification in terms of poverty alleviation?

The dissertation is organized into six chapters. The first one is the introductory chapter that first provides a picture of the Indonesian coffee sector and coffee value chain before elaborating on the conceptual framework of economic performance andproviding an overview of prevalent coffee certification schemes in Indonesia. We also provide an overview of existing studies on certification and economic performance, resulting in the three knowledge gaps presented above. We discuss the relevance of this research and elaborate on challenges encounted during the fieldwork in Indonesia.

In the second chapter, we examine the impact of coffee certification on the economic performance of Indonesian actors. In this chapter, we conceptualized economic performance as a prosperity-related indicator and operationalized it through the use of micro-economic parameters: coffee area, total coffee production, productivity, the number of coffee trees, coffee prices, the total value of the production, production costs, and profit. In this chapter we also use the concept of 'economic rent' to shape the interpretation of economic performance. We use a value chain analysis as a theoretical framework to determine the economic performance of actors in the coffee value chain andadopted different methods (questionnaire, interviews, and a focus group discussion) to answer the research questions formulated in this chapter. The specific statistical test considered here is the analysis of variance (ANOVA). We conclude that all Indonesian actors benefit financially from certification on a price per kilogram measurement, but the differences between certified and non-certified actors are small. This chapter also reveals that economic rent is unequally distributed along the coffee value chain, as roasters receive $95.46 \%$ (for Robusta) and $83.66 \%$ (for Arabica) of the total economic rent (retailers excluded). Overall, certified farmers 
produce more and better quality coffee beans resulting in higher prices per kilogram of coffee compared to the conventional farmers. In terms of profit however, we could not find significant differences between certified and conventional actors.

In the third chapter, we argue that the type of marketing channel an actor is part of, is an important mediating factor influencing the economic performance of Indonesian actors through certification. Sustainability certifications may shorten the coffee chain and therewith reduce transaction costs and market risks, and improve market access, which may positively relate to the economic performance of actors on the coffee value chain. In this chapter we conceptualize economic performance as efficiency and equity. Efficiency is further operationalized by looking at costs, profit margins, and lead times, whereas equity is measured in terms of the division of marketing and profit margins over the actors in the channels. This chapter concludes that there are significant differences in economic performance among the channels, although the most efficient channels are not necessarily the most equitable ones. Lead times are significantly shorter in the certified channels compared to the conventional and mixed channels. Overall, certified channels are generally more efficient than conventional channels. Among the channels performing relatively well in terms of economic performance, none is a conventional channel; they are either certified or mixed. We conclude that certification seems to increase the chances of a good economic performance, but is no guarantee for it. Besides, the marketing channel an actor is part seems to be more important to explain differences in economic performance than certification.

In the fourth chapter, we examine partnership constellations as another potentially mediating factor that may help to explain the effects of coffee certification on economic performance. We focus on the economic performance of three groups of smallholders; farmers participating in global certified partnership constellations, local certified partnership constellations and local conventional partnership constellations. We use a similar, but slightly adapted conceptualization of economic performance as in chapter 2 . The difference lies in the replacement of the variables of profits and costs for lead times. Via a post hoc multiple comparisons Anova-test we analysedthe differences in economic performance, whereas a regression analysis estimated the strength of the relationship between partnership constellation and economic performance. This chapter shows that farmers participating in global certified partnership constellations score better on most indicators underlying our operationalization of economic performance than farmers in local partnership constellations (both certified and conventional). This can be explained by the regular trainings and technical assistance delivered by global certified exporting companies to the farmers. The regularity of these trainings helps farmers to internalize good 
agricultural practices into their daily activities, which subsequently helps the farmers to improve the product quality and volume of production. Farmers in local certified partnership constellations do only significantly differ from farmers in local conventional partnership constellations for the coffee prices they receive. The former receive higher prices than farmers in local conventional partnership constellations. We conclude that partnership constellations and their underlying institutional factors (i.e. the provision of trainings and support) seem to play a more important role in explaining differences in economic performance than certification itself.

In the fifth chapter, we examine the impact of coffee certification on economic performance from a broader perspective by using a macroeconomic conceptualization of economic performance: poverty alleviation. In this chapter, we measure poverty from a monetary and a non-monetary approach. In the monetary approach, we compare coffee farmers' expenditure to regionally specified poverty lines. In addition, we analyse the extent to which certified and conventional farmers are deprived in education, health and standards of living. We conclude that certified farmers have a significantly lower risk to end up in non-monetary poverty than conventional farmers, but the differences are extremely small. In the monetary approach, we could not identify significant differences between certified and conventional farmers. This also implied that farmers being classified as poor in the monetary approach are not necessarily poor in the non-monetary approach. This can partially be explained through the strong social ties that play an important role among Indonesian coffee farmers and make the farmers very open to share facilities such as sanitation and drinking water. If one farmer in a village invests in the construction of facilities, all farmers may benefit from access to these. This implies that -in the Indonesian coffee production context- it seems more useful to analyse economic performance from a non-monetary approach than from a monetary approach alone.

In the sixth chapter, we summarize the main conclusions of the four empirical chapters about the effects of coffee certification on economic performance. Overall coffee certification has a positive impact on economic performance, but the effect is very small. The demand for certification is mainly determined by consumers. The more consumers who purchase certified coffee, the more collective demand of coffee certification. On the other side, most smallholder farmers adopt private sustainability standards because of financial incentives and non-monetary benefit (i.e. community development program) from certification. Thus market, financial incentives, nonmonetary benefits play crucial roles to driving sustainable coffee production. It is understandable because adoption of coffee certification requires some stringent private sustainability standards-social, economic and environment standards. We suggest certification bodies should provide market, monetary and non-monetary 
benefit to maintain farmers and exporters adopt the certification. Furthermore, in terms of public standard, the ISCoffee still needs some steps to make ISCoffee acceptable in the coffee market. The chapter closes by discussing future study needs in this field. 



\section{Ringkasan}

Asumsi yang berlaku di kalangan konsumen dari negara negara barat, membeli kopi sertifikasi berarti berkontribusi positif terhadap performa ekonomi aktor (pelaku) di negara Negara selatan. Studi-studi sebelumnya juga menunjukkan bahwa prospek ekonomi merupakan alsan kuat mengapa petani mau bergabung dalam program sertifikasi. Namun, hasil studi yang menganalisis dampak sertifikasi pada kehidupan petani masih inkonklusif. Pertama, beberapa studi mengakui sertifikasi berdampak positif secara langsung seperti pada pendapatan petani, jaminan harga minimum, dan produktivitas yang lebih tinggi. Kedua, beberapa studi menunjukkan sertifikasi berdampak negatif pada produksi kopi dan biaya produksi, serta pendapatan petani. Ketiga, studi yang lainnya menyimpulkan sertifikasi tidak mempunyai dampak pada performa ekonomi.Atas dasar inkonklusif dari hasil studi sebelumnya, maka melalui disertasi ini saya ingin berkontribusi untuk lebih memahami pengaruh sertifikasi kopi pada performa ekonomi petani kopi Indonesia. Adapun pertanyaan penelitiannya adalah:

Dalam konteks Indonesia dan karakter sertifikasi kopi, bagaimana cara yang bermanfaat untuk menganalisis dampak sertifikasi pada performa ekonomi petani?

Lebih konkritnya, disertasi ini berkontribusi pada literature melalui tiga cara yaitu:

Pertama, riset saat ini cenderung mengasumsikan hubungan kausal secara tidak langsung antara sertifikasi dan dampak ekonomi. Saya menambahkan posisi petani pada rantai nilai, dan menginterpretasikan manfaat ekonomi yang diterima petani dibandingkan dengan pelaku lainnya di rantai nilai. Perbedaan dengan riset yang sudah ada, saya membedakan kopi sertifikasi dan konvensional di rantai nilai yang interchangeable dengan menghubungkan personal interlinkages diantara pelaku pelaku lainnya. Kedua, saya mengobsevasi riset saat ini umumnya mengabaikan peran factor mediasi yang menghubungan antara sertifikasi dan performa ekonomi. Pada riset ini, saya mempertimbangkan factor mediasi yang berpotensi berpengaruh pada jenis jalur pemasaran (marketing channel) dan partnership. Ketiga, saya mengobservasi salah satu kelemahan studi saat ini terkait dari konsep performa ekonomi, konsep mikroekonomi dengan menggunakan indikator kuantitatif pada tingkat individual. Saya melakukan hal yang sama dalam disertasi ini, tetapi saya menambahkan performa ekonomi dari perspective yang lebih luas yang kemudian fokus pada indikator moneter dan non-moneter untuk mengurangi kemiskinan dengan membandingkan antara petani sertifikasi dan petani konvensional. 
Berdasarkan pertimbangan tersebut, maka saya memformulasikan pertanyaan riset yang lebih operasional yaitu:

- Bagaimana sertifkasi keberlanjutan (sustainability) berkontribusi pada performa ekonomi petani Indonesia di rantai nilai kopi.

- Bagaimana economic rent dari sertifikasi sustainability didistribusikan ke para pelaku di rantai nilai kopi dan bagaimana petani memperoleh keuntungan secara ekonomi setelah mereka bergabung dalam sertifikasi?

- Bagaimana perbedaan jalur pemasaran dan partnership mempengaruhi performa ekonomi petani?

Disertasi ini disusun ke dalam 6 bab. Pertama, bab pendahuluan yang mendeskripsikan sector kopi Indonesia dan rantai nilai kopi dengan menyediakan overview dari skema sertifikasi kopi saat ini di Indonesia. Disertasi ini juga memberikan gambaran tentang studi-studi saat ini tentang sertifikasi dan performa ekonomi, menghasilkan tiga kesenjangan pengetahuan (knowledge gaps). Kita juga mendiskusikan relevansi riset ini dan mengelaborasi rintangan yang dihadapi saat melakukan studi lapang di Indonesia.

Pada bab dua, kami menguji dampak sertifikasi kopi atas performa ekonomi aktor di Indonesia. Pada bab ini, kita mengkonsepkan performa ekonomi sebagai indikator kemakmuran. Dan dioperasionalisasikan melalui parameter mikroekonomi: luas kebun kopi, total produksi kopi, produktivitas, jumlah pohon kopi, harga kopi, total nilai kopi (pendapatan dari kopi), biaya produksi, dan keuntungan (profit). Pada bab ini saya juga menggunakan konsep economic rent untuk mempertajam interpretasi performa ekonomi. Kita menggunakan analisis rantai nilai sebagai kerangka teori untuk menentukan performa ekonomi pelaku di rantai nilai kopi dan menggunakan metode yang berbeda (kuesioner, interview, dan diskusi grup) untuk menjawab pertanyaan penelitian yang sudah diformulasikan pada bab ini. Uji statistik spesifik yang dipertimbangkan adalah analysis of variance (ANOVA). Kami menyimpulkan bahwa semua aktor Indonesia memperoleh manfaat secara finansial dari sertifikasi dalam bentuk harga per kilogram, tetapi perbedaan antara aktor yang mengadopsi sertifikasi dan aktor konvensional kecil. Bab ini juga menyatakan bahwa economic rent didistribusikan secara tidak merata di sepanjang rantai nilai ekonomi, karena roaster menerima 95,46\% untuk kopi robusta dan 83,66\% untuk kopi arabika dari total economic rent (retailers excluded). Secara umum, petani sertifikasi memproduksi lebih banyak dengan kualitas kopi yang lebih baik menghasilkan harga kopi yang lebih tinggi per kilogramnya dibadingkan petani konvensional. Tetapi untuk keuntungan, kami tidak menemukan perbedaan yang signifikan antara aktor sertifikasi dan aktor konvensional. 
Pada bab ketiga, kita berargumen bahwa jenis jalur pemasaran merupakan faktor penting yang mempengaruhi performa ekonomi Indonesia aktor melalui sertifikasi. Sertifikasi sustainability mungkin memperpendek rantai nilai kopi dan mengurangi biaya transaksi serta resiko pasar sehingga memperbaiki akses market yang kemudian berdampak pada performa ekonomi aktor di rantai nilai kopi. Pada bab ini, kami mengkonsepkan performa ekonomi sebagai efisiensi dan keadilan. Efisiensi kemudian dioperasionalkan melalui variabl biaya, margin keuntungan, dan lead times, sedangkan keadilan didefinisikan sebagai pembagian margin pemasaran dan margin keuntungan seluruh aktor di jalur pemasaran tersebut. Pada bab ini kami menyimpulkan bahwa ada perbedaan yang signifikan pada performa ekonomi antar jalur pemasaran, meskipun jalur pemasaran yang efisien belum tentu merupakan jalur pemasaran yang adil. Lead times lebih pendek untuk jalur pemasaran sertifikasi dibandingkan jalur pemasaran konvensional maupun jalur pemasaran campuran. Secara umum, jalur pemasaran sertifikasi lebih efisien daripada jalur pemasaran konvensional maupun jalur pemasaran campuran. Kami menyimpulkan bahwa sertifikasi nampaknya meningkatkan performa ekonomi yang baik, tetapi tidak ada jaminan untuk itu. Selain itu, jalur pemasaran lebih penting menerangkan perbedaan performa ekonomi daripada sertifikasi.

Pada bab empat, kami menguji konstelasi kerjasama (partnership constellations) sebagai faktor lain yang berpotensi menghubungkan dampak sertifikasi pada performa ekonomi. Kami fokus pada performa ekonomi dari 3 grup petani yaitu petani sertifikasi yang bekerjasama dengan perusahaan global, petani sertifikasi yang bekerjasama dengan perusahaan lokal dan petani konvensional yang bekerjasama dengan perusahaan lokal. Kita menggunakan konsep yang hampir sama dengan konsep yang kami gunakan pada bab dua. Perbedaannya pada variabel keuntungan dan biaya serta lead times. Berdasarkan uji ANOVA, kami menganalisis perbedaan performa ekonomi, dan analisis regresi untuk mengestimasi kekuatan hubungan antara konstelasi kerjasama dengan performa ekonomi. Bab ini menunjukkan bahwa petani sertifikasi dalam konstelasi kerjasama global mempunyai skor yang lebih baik untuk kebanyakan indikator performa ekonomi daripada petani yang berada pada konstelasi kerjasama lokal (baik sertifikasi maupun konvensional). Kondisi ini dapat dijelaskan melalui pelatihan dan bimbingan teknis (technical assisstance) reguler yang disediakan perusahaan eksportir global untuk petani. Pelatihan reguler membantu petani menginternalisasikan "good agriculture practices"dalam kehidupan mereka sehari hari sehingga memperbaiki kualitas produksi kopi dan meningkatkan volumenya. Hanya ada perbedaan harga antara petani sertifikasidan petani konvensional dalam konstelasi kerjasama lokal. Petani sertifikasi dalam konstelasi kerjasama lokal menerima harga kopi lebih tinggi daripada petani konvensional dalam konstelasi kerjasama lokal. Kami 
menyimpulkan bahwa faktor institusional (seperti pelatihan dan bantuan lainnya) nampak lebih berperan penting dalam menjelaskan performa ekonomi daripada sertifikasi itu sendiri.

Pada bab lima, kami menguji dampak sertifikasi kopi pada performa ekonomi dari perspektif yang lebih luas dengan menggunakan konsep makroekonomi yaitu pengurangan kemiskinan (poverty alleviation). Pada bab ini, kami menggunakan kemiskinan dari pendekatan moneter dan non moneter. Pada pendekatan moneter, kami tidak dapat mengidentifikasi perbedaan yang signifkan antara petani sertifikasi dan konvensional. Ini berarti petani yang diklasifikasi miskin menurut pendekatan moneter tidak serta merta menjadi petani miskin menurut pendekatan non-moneter. Hal ini diebabkan petani Indonesia memiliki keterikatan sosial yang kuat sehingga mereka saling membagi fasilitas publik seperti sanitasi dan air minum. Jika satu petani membangun fasilitas (misalnya air minum) maka petani lain juga dapat menggunakan fasilitas ini. Ini berarti untuk menganalisis performa ekonomi petani Indonesia Nampak lebih bermanfaat jika menganalisis performa ekonomi ditinjau dari pendekatan nonmoneter dibandingkan pendekatan moneter saja.

Pada bab enam, kami meringkas kesimpulan dari empat bab empiris tentang dampak sertifikasi pada performa ekonomi. Secara umum sertifikasi mempunyai dampak positif pada performa ekonomi, tetapi dampaknya sangat kecil. Permintaan sertifikasi itu terutama didorong oleh konsumen. Semakin banyak konsumen yang membeli sertifikasi kopi, semakin banyak sertifikasi kopi diadopsi. Pada sisi lain, sebagian besar petani yang mengadopsi "private sustainability standards" lebih disebabkan oleh insentif finansial dan manfaat non moneter (seperti program pembangunan komunitas) dari sertifikasi. Oleh karena itu, pasar, insentif finansial dan manfaat non moneter sangat penting untuk mendorong perkembangan sertifikasi kopi. Hal ini dapat dimengerti karena adopsi sertifikasi kopi berarti meminta petani untuk mengikuti peraturan yang lebih rumit dari private sustainability standards" terkait standar sosial, ekonomi dan lingkungan. Kami menyarankan badan sertifikasi seharusnya menyediakan pasar dan manfaat baik moneter dan non moneter agar petani dan eksportir tetap mengadopsi sertifikasi. Selanjutnya untuk sertifikasi ISCoffee sebagai public standard dibutuhkan beberapa langkah agar ISCoffee dapat diterima di pasar kopi. Bab ini diakhiri dengan merekomendasikan studi lanjutan lain di masa yang akan datang. 